\title{
A Study of Terrorism Discourse in TaifaLeo Newspaper of Kenya
}

\author{
Mr. Silas Odhiambo Owala (corresponding author) \\ School of Humanities and Social Sciences \\ Bondo University College -Kenya \\ Email: oowala2000@yahoo.com
}

\section{Dr. Florence Indede}

Department of Kiswahili and other African Languages Maseno University-Kenya Email: indede2001@yahoo.com

\section{Dr. Sangai Mohochi}

Department of Kiswahili and other African Languages Maseno University-Kenya Email: smohochi@gmail.com

\section{Doi: 10.5901/mjss.2013.v4n4p283}

\section{Abstract}

Terrorism is a global concern and usually elicits a lot of sensationalism every time it occurs. The media often finds itself in the middle of debates over this issue. Apart from the role of informing the public, the media has a responsibility of avoiding the creation of animosity amongst the readers. The choice of language used by the media can create a negative attitude towards one another among the readers and the public in general. This research investigated discourse on national and international terrorism in TaifaLeo, a daily published in Kiswahili language in Kenya. The main objective was to analyze the language used in reporting terrorism news in the newspaper. The intention was to find out how the language used in those specific news items created bias in presentation of terrorism news. The parts of the newspaper that had reports on terrorism were isolated and analyzed over a period of one year. The study revealed that there was bias in the way this newspaper reported terrorism news. The biases that were noted were mostly caused by discourse structures that were provided by either the reporters or the sources they quoted.

Keywords: Terrorism news, reporting, bias, language use

\section{Introduction}

International and national terrorism is one of the issues that is often highlighted by newspapers in Kenya and other parts of the world. In Kenya there have been incidents of terrorism for example the August $7^{\text {th }} 1998$ bombing of the American embassy in Nairobi and the bombing of a tourist hotel at Kikambala at the coast in the year 2002. Both incidents were reported in all Kenyan dailies including Taifaleo. In the reports the language used was chosen by either the news reporters or the people they quoted. The choice of language had effects on the readers of the newspaper. As a result of language use, attitude towards certain communities, enmity, suspicion and other problems often arise. This is because language used often creates bias that is responsible for developing such attitudes.

There is a relationship between this bias and ideologies of leaders of nations where various newspapers are published. This is because in theory, many countries have laws that protect freedom and of the press. However the ideologies of leaders and security agencies of many nations tend to undermine this freedom. As a result there is pressure that often influences choice of language that satisfies the desires of the government agencies and the political class. This pressure often manifests itself in the texts that appear in news articles in the newspapers.

Williams (2002) affirms that the most important thing to note when reading a newspaper is that news is often lopsided and that many times the views expressed in the news reflect the political ideologies subscribed to by the owners of the media house. 
Taifaleo Newspaper is a Kiswahili daily paper published in Nairobi Kenya by Nation Media Group. The paper is a moderate and does not have a history of open inclination towards known political wings both in this country and elsewhere. The paper publishes in moderate Kiswahili language which is both the national and official language of Kenya.

\subsection{Choice of language in discourse}

Language is the most important thing in any text. In order to pass a message, there must be some form of language use. Depending on how it is used, it can have diverse effects.

Dellinger (1990) says that any discourse includes lexical items, grammar, morphology, phonology and semantics. However these are not the only aspects used in interpreting texts. There are other social factors that affect the way text is interpreted. These factors are as a result of people's beliefs, ideologies and history in specific societies. In Kenya for example, there has been violent clashes during election years. News reports during election years can have effects on the social fabric due to that history.

An unqualified report of people in a forest with arrows can thus be interpreted to mean war and this can lead to displacement of populations even if there will be no war. This is because historically such events have led to fighting in the past.

Kaplan (1990) agrees that the world view that the writer and the recipient of text puts in the interpretation is important. Unguarded choice of language is therefore dangerous as this can make the reader interpret text in a different context. In many cases the effects of the attitude in the reporters mind often has an effect on their writing. This can happen with or without his/her knowledge. Often the language and style of the writer indicates their leaning and bias however careful they are. Readers have the ability to know the leaning of the writer.

This is the reason why in many cases where there are conflicts there are always complaints of bias by news reporters. In all such cases it is language that is often used as a tool. In the year 2011 Kenya waged war against AlShabaab of Somalia. In that war it was clear that the Kenyan media was biased towards Kenya. Most of the reporters rode with the Kenyan soldiers and mostly showed the might of the Kenyan military and very little from the Al-Shabaab side. While they may not have said openly which side they supported, the way they gave information told a different story. Apart from the structure of language there are other issues that contribute to interpretation of meaning. This is an important aspect of critical discourse analysis theory that expounds how history, ideology and politics can inform the use of language in a specific context.

In reporting a terrorist attack for example, saying an attacker wore a robe without further qualification can lead to a historical contextual interpretation. Muslims are known to wear robes and statements like that can be misleading. Using unqualified language can have as bad effect as giving biased information if not worse because it is open to varied and sometimes unintended interpretations.

Kress (1990) explains that a writer or speaker can show their bias directly by openly taking sides. However, linguistic forms can achieve the same result. A text is a choice of syntactical forms whose structure shows ideologies of specific societies. The choice of language manifests itself in text in a manner that preserves and perpetuates these ideologies.

Stroebel (2009) gives an example of how word choice can affect interpretation. He narrates an incident where FBI agents stormed a company. The purpose of that action was not immediately clear. Various newspapers gave their view about what they thought could be the reasons for the raid. In one newspaper the reporter said the owner of the company has a name similar to those from the Middle East and that the occupants of the building pray five or seven times a day. It is clear that the writer's intention was that of lumping together a group of people. This definitely had an effect of creating an attitude against the people the writer was referring to. The issue of prayers was not connected to the raid and its inclusion here had bad intentions same as the dressing. Readers of this article would have some attitude towards people who pray that number of times a day.

This kind of reporting can easily create suspicion among people in the society. This kind of use of language was investigated in this study. We wanted to find out if the paper (TaifaLeo) had news items about terrorism that guided the minds of the readers to conclusions without adequate justification.

\subsection{Bias in the Media}

Bias in this context is the way news reporters tilt the public opinion by choice of news and how they make decisions on what and how to present the news. There are various types of bias. These are mostly classified according to the cause. Some of these are:- 


\subsubsection{Political Bias}

This shows bias due to political reasons e.g. because of support for a political party; a politician or a political policy. This phenomenon is found all over the world. The Daily Telegraph and Daily Mirror are known to have an inclination towards labour party. The moment a media house gets inclined to a political party, its choice of language is carefully done to avoid appearing unpleasant to that party.

\subsubsection{Commercial Bias}

Media companies depend on commercials to stay afloat. This can create a bias as none of them would like to annoy their sponsors. In Kenya for example, the government pays a lot of money to advertise in the dailies. These include job opportunities and some documentaries about government policy. This can easily be used as a bait to make such media houses conform to government opinion on some issues. There was a time that all government advertisements were placed in a daily called Kenya Times which was very close to the ruling party then known as K.A.N.U

\subsubsection{Ownership Bias}

This usually occurs when there is a friendly relationship between the media owners and those that are quoted in the news. Newspapers are investments owned by people. The owners can therefore have a heavy influence on the news reported in the newspapers.

\subsubsection{Religious Bias}

This is a bias where news seems to glorify or scandalize a religious group. In terrorism news, there are often complaints that Muslims are suspected to be terrorists without any logical reasons. This suspicion makes reporters to write news that can sometimes appear to be biased against Muslims. While it is true that there are some Muslims who have been involved in acts of terrorism, there are many others who are opposed to it. It is also not true that all Christians are peace loving and good people. There have been criminal acts where Christians have been involved.

\subsubsection{Racial Bias}

This is based on race, gender, age, social class or tribe. In many countries with people of mixed race, the race that also belongs to a lower social class is often discriminated against gender bias is often seen when writers of news items use he or she without considering that there is more than one gender. In many newspapers, the opinion of people of a higher social class is often given more emphasis.

\subsection{Bias in terrorism news in the media}

Many authors have pointed out that the media has shown bias in reporting terrorism. Many times government have been criticized for attempting to guide the media in this regard.

Sikand (2006) expresses surprise at the manner in which terrorism discourse in India is heavily lopsided. According to him, violence by some Muslims are given prominence yet similar activities by other groups are not considered terrorist. He says this is a conspiracy between the media and politicians. He sees the violence as an act of desperation and that the media do not seem to care about the poor conditions of the majority of Muslims in India.

This view is a pointer that there are people who feel that the media takes sides in the conflicts that lead to terrorism. He also asserts that bias is directed against a specific religion. On the side of politicians this can come out in the access that they have to media coverage. The kind of people who are given access to media to give their opinion about a terrorist incident was an area of concern in this study. This is because discourse access is one of the ways of creating bias.

Martin (2007) does not agree with government policies that tend to prescribe guidance to the media by saying that people have a right to know not just about the mad men in their midst but also what makes these people risk their lives. This view was a result of the suspicion that the America government attempted to discourage the media from reporting about terrorism reasoning that this gave terrorists publicity. This is a good example of how politicians and the ruling elite have attempted to persuade the media to have a leaning when reporting about terrorism. He stresses that given the western countries claim of respect for human and democratic rights, this was not expected. It is better for people to be 
given the freedom to read the news they want and make a decision on how to receive the news. Denying readers the right to receive news sabotages democratic principles.

Wardlaw (1989) says government officers do more to erode democratic principles in the pretext of fighting terrorism than the dangers that can be caused by the terrorists.

These views are buttressed by (Huskainen 2005) an MP in Finland who said that the Western countries have a democratic background and receiving news is important in a democratic society. These views were given following an attempt by the government of Finland to support efforts to censor views of terrorists in the media claiming this will help terrorists. This is evidence that governments have made attempts to gag the media over issues related to terrorism.

Since September, 11 pressure on American Newspapers increased both in and outside America following claims of bias in favour of the American governments' "war against terror".

Wendland (2001) narrated an incident where a news reporter was sacked for criticizing President Bush over his handling of the issue. The sacking of the reporter was indicative of a relationship between the owners of media houses and government officials. The media company was private but the owners appeared unhappy with criticism of the president. The president of course did not have authority to sack the reporter. This shows how ideologies and the people they relate to affect the owners of the media and what they write.

Although we understood that TaifaLeo newspaper relies on some news agencies like Reuters, AFP and AP, this would still not be an excuse for not exercising neutrality. It is also important to note that there were news about terrorism whose source was Kenya. We investigated how the editors of this newspaper presented the news items and specifically choice of discourse structures used in their presentation.

\section{Theoretical Basis}

The grounding of this study is Critical Discourse Analysis theory (CDA). CDA is concerned with studying and analyzing written texts and spoken words to reveal the discursive sources of power, dominance, inequality and bias and how these sources are initiated, maintained, reproduced and transformed within specific social, economic, political and historical contexts. (Van Dijk 1988). The idea is to illuminate ways in which dominant forces in the society construct versions of reality that favour their interests. This paper examines how these dominant forces within a framework of discourse access and discourse structures have created bias in terrorism news.

\section{Methodology}

\subsection{Sampling Procedure}

TaifaLeo newspaper a Kiswahili daily published in Kenya was studied. Some of the news on terrorism in TaifaLeo between November 2010 to October 2011- were selected for, analysis.

\subsection{Data Collection}

The parts of the paper that had news on terrorism were isolated and copied.

\subsection{Data Analysis and Presentation}

After isolating the parts of the newspaper that had news on terrorism, the items were analyzed to identify the areas that had bias. The following guideline was used to identify the bias:-

- The use of personal pronouns to include masses in personal opinions.

- Use of adjectives intended to negatively portray the suspects.

- The part of the sentence where negative information about the suspects has been placed.

- Use of rhetoric by speakers on terrorism to look for support or sympathy.

- The access given to various people to give their opinion on terrorist incidents

We then went on to explain how these aspects of discourse structures led to bias in presentation of news items related to terrorism. 


\section{Findings And Discussions}

\subsection{Bias in News}

The analysis indicated that there were times when both sides were given access and therefore got a chance to speak. However, these cases were very few on $15^{\text {th }}$ January, 2011 there was a news item "Al-Qaeda admits kidnapping". This quotation was from Al-Qaeda's website admitting responsibility for a kidnapping incident. The French government also had an input where they expressed their suspicion that Al-Qaeda was responsible. This did appear to give access to both sides of the divide.

In the issue of January $19^{\text {th }}$ where 14 people were killed, its only the police who were given the chance to speak about the incident. There is no indication of an attempt to get information from the other side. The decision to get information only from the police is in discourse access a form of bias. This is because the police is an agency of the government and in many cases they give statements that are heavily censored by the governments they represent.

On January $24^{\text {th }}$ a news item read "attack kills 2". In the report, more emphasis was placed on the death of a policeman in the attack. Nothing was said about the other person who was also killed in the same incident. It appears that the spokesman wanted the sympathy of the police force. The spokesman was an officer of the Ministry of Interior. Stressing the death of the policeman would therefore make it easier for the government to rally the police in fighting 'terrorism' knowing that they are in danger of losing their lives.

January $26^{\text {th }}$ had an AFP report entitled "Obama condemns attack on airport" a section of that report read "world leaders condemn bomb attack". Only six leaders condemned the attack. These were leaders of Germany, Britain, France, Israel, Australia and America. The use of world leaders was an attempt to include the whole world obviously to isolate those involved in the attack. The idea that when leaders of six nations speak then the world has spoken is a form of generalization. It does not give a chance for people to hear more about what happened. The tone of the report is conclusive.

British Prime Minister David Cameron was quoted saying "The world should not accept to be ruled by terrorists". This statement made it appear that the whole world was on one side and terrorists the other side creating an impression of "them" against "us". French and German presidents described the act as "cowardly". This word was meant to demean the attackers. These attackers many times take such act as "bravery" and not "cowardly". Although the use of the word was not generated by the newspaper, the bias is still there from the source of the news. It was still the decision of the paper to publish it.

In a similar tone Israeli Prime Minister Benjamin Netanyahu said "we shall join our forces, terrorists will not make us accept defeat, and we must agree and ensure their schemes are defeated". This was definitely an attempt to make it appear that the whole world was on his side. The Israeli prime minister did not say with whom they were going to join their forces. The assumption here is that it is with "the rest of the world" against the "terrorists".

Throughout the discourse, there was no news on why the attack took place, who were involved and why. Reporters could get this information if they wanted to but they either did not look for it or if they did, they did not think it was necessary to print it. On the same page there was a photograph showing a small child, a woman, and an old man. The choice of that photograph was deliberate - to show that those affected were least able to defend themselves. The photograph completes a news item that was well planned to portray the attackers as enemies who should be isolated. The writer had more interest in what these leaders said, it was more important to the writer than humanitarian efforts going on. The writer presented a lopsided report by giving discourse access only to those leaders.

On $2^{\text {nd }}$ February 2011, TaifaLeo published terrorism news with the title "Suicide bomber kills many in city". The news was about a terrorist attack in Pakistan where three policemen were killed. There were others who were injured. This was an example of exaggeration to achieve certain objectives. There was no justification for using the word "many" for three. Whether it was the police officer who was quoted or the news reporter, the content of that news item did not tally with the headline. This bias must have been deliberately crafted to achieve some objective.

On the issue of $11^{\text {th }}$ March 2011 there was news with the title "person who planned to attack America in court". The content under this title did not reflect this title. First it is ridiculous that a single person was going to attack such a big nation. The person arrested, it was alleged, planned to attack the house of former president George Bush in Dallas. How that translates into attacking America is not easy to understand. The idea here was to make all Americans feel they were under attack perhaps with an intention of rallying them together to support the governments stand. The person quoted in this news item was an F.B.I. agent. The headline deliberately tilted the news. It was not difficult to say "a person who planned to attack Bush's house arraigned in court". This would have been more accurate reporting. In 
quoting a biased agent, the paper contributed to the bias. This is the danger of media relying on government agencies for information. They cannot be relied upon to give unbiased information or view.

On April, $29^{\text {th }} 2011$ the paper published on its front page a story "Al-Qaeda recruitment in Mosques." The origin of this story was Kenya. A close analysis showed that the content of the story was different from the headline. The story was about how Al-Shaabab was recruiting fighters for the war in Somalia within three mosques in Mombasa. The writer of this story used Al-Qaeda instead of Al-Shaabab. Al-Qaeda is usually associated more with terrorism. At the time this story was written the association between the two groups had not been consummated. This is an example of how bias can be created by a writer. The use of Al-Qaeda on the headline then go on to write about Al-Shaabab gave the impression that the two names could be used interchangeably or that Al-Shaabab and Al-Qaeda is the same group yet at the time it was not.

It is not possible that the story writer did not know the difference between those two groups. Stories are also edited before publication. This means that this story was published with the knowledge of the editors.

The month of May 2011 had a lot of stories on terrorism. This was because of the death of Osama Bin Laden the leader of Al-Qaeda. Osama was killed by American soldiers in Pakistan. On $3^{\text {rd }}$ of May 2011; Taifaleo had a headline "Obama dims Osama." This headline was written in bold. The headline is a play of words that appeared to glorify the American President. This play of words does not show neutrality on the part of the reporter. In introducing the news, the reporter wrote "the leader of the terrorist group Al-Qaeda was finally killed in a heroic attack mounted by American soldiers in Pakistan." This foregrounding was clearly biased; he described opposing sides in the conflict differently. American soldiers as heroes and Osama as a leader of a terrorist group. The learning of this writer is unmistakable. The choice of words by the writer was influenced by his attitude towards the group. According to Van Dijk 1993:262 the attitude a person has, has an influence on their views of various issues. That attitude affects their writing and thus appears in the texts they present. In the same story there was a photograph of both Osama and Obama with the latter laughing. This photograph also shows the writers mind - that Osama's death was pleasant. None of the news bulletins that we know of including TV appearances of Obama during that period showed him laughing. He took a photo of Obama laughing probably from a different event and put it in this item. This was creativity but its effects can be unpleasant.

On the following page, the paper wrote "Osama blasted and body thrown" In the story that followed this headline, the reporter wrote that Osama was shot in the head. This is not the same as blasted that appeared in the headline. The reporter it appears used the word blasted in a celebratory manner, another indicator that his opinion and leaning was allowed to get into the text. This greatly affected the news he presented and created a clear bias in presenting news on terrorism in this newspaper. In other stories within the same issue, those quoted were chosen in a lopsided manner. A woman was quoted as saying "this is a miracle, the attack (September 11) changed New York and ten years later we are victorious" This statement was inclusive of all Americans insinuating that all Americans were happy with Osama's death. If the reporter wanted to get views of people with different opinions he could have done so but he did not. His leaning may have prevented him from seeking diverse opinions over the issue.

In the same paper on page 2 there are six photographs of people. The headline reads "Kenyans happy with death of criminal." This is in reference to the death of Osama. Six people cannot be a representative of the views of all Kenyans. There is no evidence that a scientific method of doing survey to determine the view of Kenyans was used. These were views of the reporter and possibly justified by using the six whose photos were published therein. We know this because in the same newspaper there was a report with the title "SUPKEM branch condemns Bin Laden killing." SUPKEM is the Supreme Council of Kenya Muslims. The following in an excerpt of what another reporter wrote:

Muslim leaders in Malindi received the news of the killing of the leader of a terrorist group Osama Bin Laden with anger. The leaders said his death and the way it was publicized world wide was a plot by Americans and their allies to make Islam a laughing stock and an attempt to associate Islam with terrorism. This is a plot by America and Israel to publicize the death in a manner that demeans Islam.

Those who issued this statement were also Kenyans. However, it is also worth noting that these Muslim leaders also created a leaning by introducing a religious aspect to the saga. Israel did not participate in the killing of Bin Laden. The idea of bringing in Israel and Islam was meant to tilt the news to make it appear that Islam is under threat. This kind of generalization can easily create enmity between Muslims and other communities.

In the same issue there was a photo of a woman who was identified by name. The woman was working in Paradise Hotel in Kikambala Kenya when there was a terrorist attack on the hotel in 2002. The paper wrote, "She was 'celebrating' the death of Osama". It was not a good idea to put both the photo and the name of the woman in the media 
as this put her life to danger. If there were Bin Laden's supporters in that region, the reporter had put this woman in harm's way. Here bias has been carried too far to the extent of putting an innocent person in danger.

On page 9 there was a story with the title "Al-Qaeda promises war following Osama's death" In the story a group that supported Osama said "the holy war will continue". This group was trying to make this a religious issue by insinuating that Osama died as a result of his faith and that those of similar faith should therefore rise up and fight to defend the faith. This is an example of the use of language to rally people towards a cause that may not necessarily be relevant to all the people included in the call.

We had earlier said that one of the reasons why news about terrorism can be biased is because government agencies attempt to censor the news that newspapers write. An example of this was confirmed by a story in Taifaleo of $6^{\text {th }}$ May 2011 page 6. President Obama is quoted as saying that photos of "Osama will create unrest". This quote illustrates our point that there is some form of editing done by governments so that the news that gets into public domain is not wholly neutral. In that story Obama said: "It's important for us to make sure that a lot of information about the person who was shot is not circulated to create unrest as a propaganda tool. We are not like that and you know we do not give out these things like trophies".

From this story, there is an attempt to guide people's minds by giving information in convenient doses. Publishing news from this kind of source then as it was done in Taifaleo can make the paper biased. Although the bias came from the source, the paper takes responsibility for accepting to use that particular source. At least this choice is not thrust upon the editors.

One of the objectives of Critical Discourse Analysis is to show how the ruling elite use their agencies through the media to control the minds of masses for their own benefit. This greatly affects newspaper texts and social relationships. The society does not realize that they receive news from the point of view of the ruling elite thereby influencing their point of view too. Most times those views are shaped by ideologies resulting from certain standpoints.

A story published in Taifaleo on May $7^{\text {th }} 2011$ had the heading "group confirms leaders death." This heading looks fairly unbiased. However the lead sentence says "Terrorist group Al-Qaeda yesterday confirmed the death of its leader Osama Bin Laden and threatened retaliation." The word 'terrorist' added to the sentence tilts the news by passing judgment on the group. Why did the writer not just say Al-Qaeda without adding the word "terrorist" which is unlikely the spokesman of the group he was quoting used? In this story the bias was also shown on the part of someone who spoke on behalf of Muslims. He was quoted as follows "we appeal to our Muslims in Pakistan where Sheikh Osama was killed to demonstrate to clean up the shame put on them by betrayers and thieves who sold everything to the enemy." The Muslim leader's words suggest that they own the Muslims. This is because of his use of the possessive 'our'. Basically the use of this word in a sense is correct because these religious leaders control the minds of their followers. This makes their followers do anything they order without asking questions.

Earlier we had explained that news and information can be tilted by using words in such a manner that is meant to have an influence on both thinking of the readers and the masses in general. Osama bin Laden was well aware of this. TaifaLeo of $25^{\text {th }}$ June published a story that clearly helps to illustrate our point. It had the heading "Osama feared disintegration of group". He was quoted in a letter he wrote as saying "The problem with the name Al-Qaeda is that it did not have a religious theme that appeals to Muslims worldwide that they are in a holy war against America. Maybe a name like Taifat al-Tawhed wal Jihad which means one religion with Jihad would be better or Tamaat l'Adat al Khalifat alRashida which means the return of Khalifa." This letter is proof that words can be used to manipulate the minds of people in issues of terrorism. Osama knew that a word with a religious appeal was more suitable in sustaining his movement. He recognized language as an important tool in achieving that objective and hence his search for a more appealing word. He was concerned about the use of words like Islamic fundamentalists, mass killers and terrorists in describing his group. He knew these words affected his movement.

\section{Conclusion}

This paper has shown that there is bias in the way terrorism news is presented in TaifaLeo newspaper. Some of the bias originates from the sources of the news they write. Still others are a creation of the reporters of the newspaper either consciously or unconsciously-either way the result is the same. The main causes of this bias as evidenced in the findings are discourse access and the subsequent discourse structures used in the presentation of the news. Those who got the chance to have their opinions heard in issues of terrorism were mainly the reporters of the news, religious leaders, government security agents and politicians. This access was given to these people by the newspaper. This made the news about terrorism lopsided because they gave information that defended their own interest. It is this access that 
contributed to the discourse structures chosen and thereby creating the bias. The bias affected the readers because they were not able to get all the information they need to know about the terrorism incidents reported.

\section{References}

Al-Qaeda yakiri iliteka nyara (2011 January 15) TaifaLeo p.9

Aliyepanga kushambulia Amerika ashtakiwa (2011 March 11) TaifaLeo p.9

Al-Qaeda yaahidi vita kufuatia kifo cha Osama (2011 May 03) TaifaLeo p.9

Dellinger, B. (1995) Critical discourse analysis. Vaasa:Universitas Wasaensis

Fairclough, (1995). Media discourse. London: Edward Arnold

Hurskainen, S. (2005). Report on media and terrorism. Strasbourg: PACE

Kaplan, R. (1990). Concluding Essay : On applied linguistics and discourse analysis. Annual Review of Applied Linguistics, Vol. II.

Kibirige, A. (2011 April 29) Al-Qaeda: wasajliwa misikitini. TaifaLeo p.1-2

Kress, $G$ and Hodge, B (1979) Language and Ideology London: Routledge \& Kegan Paul

Kifo cha Osama chaongeza tumaini la Obama uchaguzini. (2011 Mei 3) TaifaLeo p.3

Kundi lathibitisha kifo cha kiongozi. (2011 Mei 7) TaifaLeo p.9

Mashambulizi yawaua wengi. (2011 Januari 24) TaifaLeo p.9

Martin, A (2002) The Right of Self- Defence under International Law-the response to the Terrorist Attacks of 11 September (http://www.aph.gov..Aullibrary/pubs/ClB/2001-02/02cib08htm)

Mogire, G. (2011 Mei 3) Obama amzima Osama. TaifaLeo p.1-2

Mutua, D. (2011 Juni 12) Mkuu wa AL-Qaeda auawa. TaifaLeo p.1-2

Obama asema picha za Osama zitachochea fujo. ( 2011 Mei 6) TaifaLeo p.9

Osama alikuwa na hofu ya kundi kusambaratika. (2011 Juni 25) TaifaLeo p.9

Ringa, M. (2011 Mei 3) Tawi la SUPKEM lalaani mauaji ya Laden. TaifaLeo p.4

Sikand, Y. (2006). The discourse on terrorism and the missing muslim voice. Retrieved from www.countercurrents.org. 11/11/2011

Soriano, M.R.T. (2008) Terrorism and the mass media after al qaeda: Athena Intelligence Journal Vol 3 No 1(2008) pp 1-20 ISSN 19985237

Stroebel, J. (2009). News bias by irrelevant facts and word choice.retrieved from http://julie-stroebel.suit101.com/news

Van Dijk, T.A (1993). Discourse and society London: Sage

Van Dijk, T.A (1993). Elite discourse and racism Newbury Park

Van Dijk, T.A. (1988). News as discourse. Hillsdale, NJ: Lawrence Eribaum.

Wakenya wafurahia kuuawa kwa mhalifu. (2011 Mei 3) TaifaLeo p.9

Wataalam: Huu sio mwisho wa ugaidi. (2011 Mei 3) TaifaLeo p.9

Wardlaw, G. (1989). Political Terrorism: Theory, Tactics and countermeasures (2nd ed.). NewYork: Cambridge University Press.

Wendland, M. (2001) Sites Track post 9/11 censorship incidents. http://www.poynter.org/web/111601 mike.htm November 16, 2001.

Williams, R. (2002). Analysing a newspaper story. London: Royton and Crompton

Wodak, R. na Van Dijk, T. (2000). Racism at the top: Parliamentary discourse on ethnic issues in six European states. Klagenfurt: Drava Verlag 